\title{
The Regional Heterogeneity of Productivity Determinants: Evidence from Ukrainian Firms
}

\begin{abstract}
This paper studies the determinants of the total factor productivity (TFP) for Ukrainian firms in the manufacturing sector across macro-regions using recent micro-level datasets for 2013. Our empirical results show some degree of heterogeneity across Ukrainian macro-regions; in particular, the link between the total factor productivity, firm size, imports and the level of competition seems to be valid for all macro regions. However, the effects of private ownership status, capital intensity and exports seems to be region specific. In addition, we found no relationship between firm productivity and foreign ownership for any of the regions.
\end{abstract}

Keywords

Firms $\cdot$ productivity $\cdot$ regions $\cdot$ Ukraine

(C) University of Warsaw - Faculty of Geography and Regional Studies
Andrzej Cieślik, Jan Jakub Michałek, Iryna Nasadiuk

Department of Macroeconomics and International Trade Theory Faculty of Economic Sciences, University of Warsaw,

Poland

e-mail: cieslik@wne.uw.edu.p

e-mail:michalek@wne.uw.edu.p

e-mail: irenas_ua@yahoo.com

Received: 23 June 2016

Accepted: 15 February 2017

\section{Introduction}

After the collapse of the Soviet Union in 1991, Ukraine emerged as an independent country and followed its own system of economic and political transition. Since the beginning of the 1990s Ukraine has been struggling to transform its economy from a central planning system into an open market economy. The change in political leadership and the declarations for deeper economic reforms as well as the recent signing of a free trade agreement with the EU, creates new opportunities and prospects for economic recovery and the improved performance of Ukrainian enterprises. However, up until now there has been relatively little empirical evidence on the performance of Ukrainian enterprises, especially in the regional context. Therefore, we aim to fill at least a part of the existing gap in the literature by contributing to a better understanding of total factor productivity (TFP) determinants in an economy that is completing the transition from a centrally planned system to an open market one.

The main goal of this paper is to empirically study the nexus between TFP, capital intensity, firm size, the level of competition in the industry, ownership status, and firm internationalization (exports and imports) of Ukrainian firms located in various macroregions, having controlled for industry-specific effects. Our study is based on Ukrainian firm-level data for the year 2013. This has allowed us to evaluate whether the determinants of productivity in manufacturing sectors are different across various regions of Ukraine.

This paper relates to the rapidly growing and recent strand in empirical literature that focuses on firm-level TFP determinants. The majority of this literature is devoted to the analysis of firmlevel determinants of TFP at the country level. ${ }^{1}$ There have been

${ }^{1}$ Given the fact that the quantity of this literature is enormous, summarizing it goes beyond the scope of this paper. An extensive review of the literature on TFP determinants has been offered by Syverson (2011). Instead, this paper discusses only studies that focus on Ukraine. several studies on the performance of enterprises in Ukraine, for example, Pivovarsky (2003) analysed the impact of ownership concentration on firm performance, while Brown et al. (2006) studied the effect of privatization on total factor productivity. More recently, Earle et al. (2014) demonstrated that political favouritism combined with weak institutions had a substantial redistributional impact on productivity. Most recently, Kim etal. (2015) demonstrated that overall improvements in firm productivity within Ukraine's manufacturing sector were found to vary substantially by industry, trade status and firm turnover; while Shepotylo and Vakhitov (2015) identified the effect of service liberalization on the TFP of manufacturing firms.

However, so far no attempts have been made to study, empirically, the relationship between productivity and firm characteristics of Ukrainian enterprises in particular regions.

In contrast to other studies, which are often based on simple labour productivity measures, this paper uses TFP as a measure of overall productivity, calculated using the LevinsohnPetrin (2003) method. In particular we have studied the role of firm characteristics such as internationalization (measured by foreign capital participation), exports and imported inputs, firm size, private ownership, and the level of market concentration within the industry. We were also able to control for industry effects. The structure of this paper is as follows. In the following section we present the empirical methodology and discuss the properties of the dataset. We then present our empirical results. In the final section we summarize, and conclude with directions for future studies.

\section{Research and Statistical Data Methodology}

In this empirical research we study the firm-level determinants of productivity. We take into account both firm and industry characteristics that may be related to firm productivity, such as capital intensity, size, ownership status, the level of competition 
in the industry as well as firm internationalization (exports and imports). ${ }^{2}$

To empirically investigate the relationship between firm productivity (measured by its TFP) and its determinants, we estimate the following regression in a log-linear form:

$\operatorname{In} T F P_{i j r}=\alpha_{0}+\alpha_{1}$ In size $i j r+\alpha_{2} \ln$ KLration $_{i j r}+\alpha_{3}$ import $_{i j r}+$

$+\alpha_{4}$ export $_{i j r}+\alpha_{5}$ private $_{i j r}+\alpha_{6}$ foreign $_{i j r}+\alpha_{7} \ln H H I_{j}+v_{j}+u_{r}+\varepsilon_{i j r}$

where TFP iir is the productivity level of firm $i$ in industry $j$ in region $r$, size ${ }_{i j i}$ is the firm size measured in terms of full-time employees, $K \mathrm{Kratio}_{i j r}$ is the stock of fixed assets per full time employee, imports iij $_{\text {ir }}$ is a dummy variable indicating whether the firm is importing or not, export ij is a dummy variable indicating whether the firm is exporting or not, private $_{i j}$ is a dummy variable indicating whether the firm is privately owned or not, foreign $_{i j r}$ is a dummy variable indicating whether the firm has foreign ownership or not, $\mathrm{HHI}_{\text {, }}$ is the Herfindahl-Hirschman index calculated for the NACE 2-digit industry, $v_{j}$ is a dummy variable measuring the industry-specific fixed effect, $u_{r}$ is a dummy variable measuring the region-specific fixed effect, $\varepsilon_{i i r}$ is the error term that is assumed to be independent of explanatory variables, and $\alpha$ s are parameters to be estimated by the ordinary least squares method. ${ }^{3}$

The data for the empirical study comes from several statistical sources and is for the year 2013. The choice of year for the analysis was determined by the availability of firm-level trade data (export and import). ${ }^{4}$ The main source of data is from Derzhkomstat (2015), the State Committee of Statistics of Ukraine, which collects data on all Ukrainian firms. Statistical information can be obtained for the purpose of scientific research. This data reflects the balance and income statement indicators related to fixed assets, total revenues, total labour costs, cost of materials, among others. Data on employment (total number of full-time workers) was obtained from employment authorities. Data on export and import operations comes from the External Economic Activity Database of the State Committee of Statistics of Ukraine. Data on domestic and foreign ownership also comes from the State Committee of Statistics of Ukraine.

The data is classified according to the KVED-2010 statistics classification, which became active on January $11^{\text {st }}, 2012 .{ }^{5}$ KVED is Ukraine's national classification, developed by the State Committee for Technical Regulation and Consumer Policy in order to collect information on economic activity. In 2013, according to the new KVED-2010 system, three agricultural industries, five mining industries, twenty-five manufacturing industries, and fiftysix services industries were identified. In this paper we focused our attention on the manufacturing industries only. ${ }^{6}$

Since the distribution of economic activity across Ukraine is

"In this paper we refer to the so-called "learning-by-exporting" hypothesis. However another strand in the international trade theory literature, initiated by Melitz (2003), has advanced the opposite relationship called the "self-selection" hypothesis, i.e. more productive firms have a higher probability of becoming exporters. Extensive summaries of empirical evidence on the relationships between firm productivity and exporting in particular countries were offered by Wagner $(2007,2012)$. In the context of Ukraine the "self-selection" hypothesis was has recently been studied by Cieślik et al. (2015).

${ }^{3}$ We estimated the model in logarithms to obtain a standard interpretation of the estimated parameters in terms of elasticities. We did not take logarithms of the dummy variables.

${ }^{4}$ Since firm-level trade data is available only for one year it is not possible to employ a panel data analysis.

${ }^{5}$ Before KVED-2010, the KVED-2005 classification was used. The industries in 2005 differed from the industries in 2013 due to a change in the classification KVED, which followed changes in international NACE classification. In 2005, Ukrainian enterprises were classified into three agricultural industries, five mining industries, twenty-three manufacturing industries and twenty-eight services industries sectors.

${ }^{6}$ The list of manufacturing industries used in this study is provided in Table A1. and the size distribution of firms in Table A2. in the Appendix. uneven, our analysis focused on five macro-regions: northern, southern, central, eastern and western. The northern region includes regions with the capitals Zhytomyr, Kyiv, Sumy, and Chernihiv; the southern region, Crimea, Mykolaiv, Odesa, and Kherson; the western region, Lutsk, Uhzgorod, Ivano-Frankivsk, Lviv, Rivne, Ternopil, Khmelnytskyi, and Chernivtsi; the central region, Vinnytsia, Kirovograd, Cherkasy, and Poltava, and the eastern region, Dnipro (former Dnipropetrovsk), Donetsk, Zaporizhia, Luhansk, and Kharkiv. ${ }^{7}$

The major cities and industrial hubs are Kyiv, Dnipro, Lviv, Kharkiv and Odesa. Kyiv is the capital, and financial and service centre of the country, and is where the headquarters of national companies and international business representatives are located. Kharkiv is the regional centre for machine-building industries, while Dnipro is the regional hub for resource extraction and metallurgy industries. The Odesa region is the gateway to the sea for transportation and logistics business, while the Lviv region is the region of middle and small scale business, which benefit from proximity to the European Union.

The definitions of the variables used in our empirical study and a summary of their statistics, are reported in Table $1 .{ }^{8}$

The level of firm productivity was measured by the TFP, calculated on the basis of the Levinsohn-Petrin (2003) methodology in statistical package STATA. The following variables were used to calculate the input shares at the 2-digit sector level: total revenue (UAH), fixed assets at the end of period (UAH), the number of employees (the number of people), the cost of materials (materials, fuel, electricity, in UAH) ${ }^{9}$

The degree of competition within the sector was measured using the Herfindahl-Hirschman Index ( $\mathrm{HHI})$. This is a commonly used measure of market concentration in the empirical industrial organization literature. It is calculated for each of the available KVED industries so that

$H H I_{j}=\sum_{i=1}^{N}\left(\frac{T R_{i}}{\sec T R} * 100\right)_{j}{ }^{2}$,

where $N$ is the number of enterprises in industry $j, T R$ is the total revenue of the enterprise $i, \sec T R$ is the sum of the total revenues of all enterprises in industry $j$. A higher value of $\mathrm{HHI}$ indicates a greater level of industry concentration.

\section{Results of the Estimation}

In this section we present the results of the estimation. We regressed the TFP variable on a set of firm characteristics, such as, internationalization measured by foreign capital participation, exports and imported inputs, firm size, private ownership, and the level of market concentration in the industry. Our results of the estimation are reported in Table 2.

First, we discuss the benchmark results for the manufacturing sector obtained for the whole country, and then separate the results for each macro-region, first having controlled for industry specific effects. In column (1) of Table 2 . we present the baseline results for all macro-regions. It turns out that only some of our explanatory variables are statistically significant. In particular, the estimated coefficient for the firm size variable is statistically significant at the $5 \%$ level and displays an unexpected negative sign. This surprising result may be due to the fact that big, formerly state-owned firms did not go through a process of effective restructuring and remained inefficient.

The estimated coefficient for the capital to labour ratio variable displays an expected positive sign, but it is not

${ }^{7}$ The key characteristics of the Ukrainian regions are provided in Table A3, while the regional distribution of firms is in Table A4 in the Appendix.

${ }^{8}$ The correlations between our explanatory variables are reported in the Appendix (Table A5).

${ }^{9}$ The estimation of input shares was performed for all 2-digit sectors. 
MISCELLANEA GEOGRAPHICA - REGIONAL STUDIES ON DEVELOPMENT

Vol. $21 \cdot$ No. $1 \cdot 2017 \cdot$ pp. 44-50 • ISSN: 2084-6118 • DOI: 10.1515/mgrsd-2017-0004

Table 1. Definitions of variables and summary statistics

\begin{tabular}{|c|c|c|c|c|c|c|}
\hline Variable & Description & Obs. & Mean & Std. Dev. & Min. & Max. \\
\hline TFP & $\begin{array}{c}\text { Total factor productivity, calculation based on } \\
\text { Levinsohn-Petrin input shares }\end{array}$ & 11,556 & 188.81 & 839.98 & .17 & $52,215.16$ \\
\hline Size & Total number of full-time employees & 11,556 & 130.03 & 754.72 & 1 & 35625 \\
\hline KLratio & $\begin{array}{c}\text { Capital to labour ratio, calculated as the ratio } \\
\text { of fixed assets to the number of employees, } \\
\text { for the end of period }\end{array}$ & 11,556 & $2,475.68$ & $40,136.68$ & .03125 & $3,762,930$ \\
\hline import & $\begin{array}{c}\text { Dummy variable indicating whether an } \\
\text { enterprise imports or not }\end{array}$ & 11,556 & .0829872 & .2758748 & 0 & 1 \\
\hline export & $\begin{array}{c}\text { Dummy variable indicating whether an } \\
\text { enterprise exports or not }\end{array}$ & 11,556 & .0964867 & .2952703 & 0 & 1 \\
\hline private & $\begin{array}{r}\text { Dummy variable indicating the private } \\
\text { ownership of an enterprise }\end{array}$ & 11,556 & .8192281 & .3848457 & 0 & 1 \\
\hline foreign & $\begin{array}{c}\text { Dummy variable indicating foreign ownership } \\
\text { of an enterprise }\end{array}$ & 11,556 & .0054517 & .0736374 & 0 \\
\hline HHI & $\begin{array}{c}\text { Herfindahl-Hirschman index for NACE 2-digit } \\
\text { industry }\end{array}$ & 11,556 & 323.85 & 287.53 & 96.08 & $1,929.94$ \\
\hline
\end{tabular}

Note: the values in the table are reported in absolute terms.

Source: Own calculations of the authors

Table 2. Results of the estimation for the manufacturing sector across macro-regions

\begin{tabular}{|c|c|c|c|c|c|c|}
\hline & All regions & Northern & Southern & Western & Central & Eastern \\
\hline- & 1 & 2 & 3 & 4 & 5 & 6 \\
\hline \multirow[t]{2}{*}{ InSize } & -.071 & -.033 & -.114 & -.092 & -.094 & -.066 \\
\hline & $(10.57)^{\star *}$ & $(2.37)^{\star}$ & $(5.60)^{\star *}$ & $(5.89)^{\star \star}$ & $(4.98)^{\star \star}$ & $(5.78)^{* *}$ \\
\hline \multirow[t]{2}{*}{ InKLratio } & .007 & .024 & -.010 & -.008 & .028 & -.002 \\
\hline & (1.54) & $(2.72)^{\star *}$ & $(0.69)$ & $(0.67)$ & $(1.90)$ & $(0.22)$ \\
\hline \multirow{2}{*}{ import } & .611 & .740 & .458 & .613 & .298 & .524 \\
\hline & $(15.94)^{* *}$ & $(10.62)^{\star *}$ & $(3.69)^{* *}$ & $(7.76)^{* *}$ & $(2.17)^{*}$ & $(7.38)^{\star *}$ \\
\hline \multirow[t]{2}{*}{ export } & .083 & -.031 & .268 & .150 & .304 & .112 \\
\hline & $(2.30)^{*}$ & $(0.42)$ & $(2.37)^{*}$ & $(2.15)^{*}$ & $(2.60)^{\star \star}$ & $(1.70)$ \\
\hline \multirow[t]{2}{*}{ private } & -.009 & .063 & -.051 & -.143 & -.157 & .071 \\
\hline & $(0.34)$ & $(1.10)$ & $(0.71)$ & $(2.47)^{*}$ & $(2.31)^{*}$ & $(1.54)$ \\
\hline \multirow[t]{2}{*}{ foreign } & .009 & -.050 & -.337 & -.420 & .076 & .181 \\
\hline & $(0.07)$ & $(0.22)$ & $(0.50)$ & $(1.44)$ & $(0.21)$ & $(0.88)$ \\
\hline \multirow[t]{2}{*}{$\mathrm{InHHI}$} & .685 & .405 & .380 & .839 & .827 & .852 \\
\hline & $(13.13)^{* *}$ & $(4.08)^{\star \star}$ & $(2.19)^{\star}$ & $(6.76)^{\star \star}$ & $(4.25)^{\star \star}$ & $(10.12)^{\star \star}$ \\
\hline \multirow[t]{2}{*}{ Constant } & 0.450 & 1,632 & 2,263 & -0.247 & -0.276 & -0.280 \\
\hline & $(1.64)$ & $(3.07)^{\star *}$ & $(2.48)^{\star}$ & $(0.38)$ & $(0.27)$ & $(0.63)$ \\
\hline Observations & 11,556 & 3,226 & 1,301 & 2,119 & 1,227 & 3,683 \\
\hline R-squared & .50 & .53 & .49 & .55 & .49 & .49 \\
\hline
\end{tabular}

Note: The absolute value of $t$ statistics is in parentheses , * significant at $5 \%$; ** significant at $1 \%$ Source: Own calculations of the authors 
statistically significant. The estimated coefficients for the variables measuring internationalization of firms, including exports and imports, display positive signs and are statistically significant although at different levels of statistical significance, being at $10 \%$ and $5 \%$ levels, respectively. This confirms the importance of international trade for firm productivity. The variable describing foreign ownership is not statistically significant at all, which may reflect a relatively low level of inward foreign direct investment in Ukraine. The estimated parameter for the private ownership variable is also not statistically significant, which does not support the view that privately-owned firms are more efficient. Finally, we find that market structure is important in determining the TFP. In particular, we find that firm productivity increases with a higher value of the $\mathrm{HHI}$. This means that higher concentrations within the industry may increase firm productivity.

In the remaining columns of Table 2. is shown the separate estimation results for the specific macro-regions in Ukraine. We find that in all the regions the firm size, import and $\mathrm{HHI}$ are statistically significant although at different levels of significance. The importance of exports for the productivity of Ukrainian firms is quite limited. Only in the case of three of the regions; southern, western and central, do exports matter, while they are not statistically significant in the cases of the northern and eastern regions. Foreign ownership is not significant in any of the regions, while private ownership is statistically significant at $10 \%$ in the western and central regions only, but it displays an unexpected negative sign. Finally, the estimated parameter for the capital/ labour ratio is statistically significant at $5 \%$ in one region only, the northern region, and displays an expected positive sign.

\section{Conclusions}

In this paper have we investigated the determinants of the productivity of Ukrainian firms across the macro-regions. The study was based on firm-level data for the manufacturing sector and was for the year 2013. The overall results (pooled data) for all regions showed that the majority of standard explanatory variables related to firm productivity were statistically significant. In particular, the capital labour ratio, export, import and $\mathrm{HHI}$ were statistically significant and revealed the expected signs. On the other hand, the variables reflecting ownership of firms were not statistically significant.

At the same time, the estimations of determinants for firm productivity for particular macro-regions reveal some degree of heterogeneity across Ukraine. In the case of all the regions, the firm size, import and $\mathrm{HHI}$ were statistically significant. The estimated coefficient for the export variable was statistically significant in the majority of regions, while foreign ownership was not significant at all. This probably means that the opening up of Ukrainian regions and the inflow of foreign direct investments is still very limited. The largest number of statistically significant explanatory variables, which were in line with expectations (five), were observable in the central and western regions, while the lowest (three) were in the Eastern region.

In future studies it would be desirable to investigate the effects of the implementation of the preferential agreement with the EU, which should increase the role of firm internationalization. Moreover, it is well documented that TFP measures may exhibit spatial associations at the regional level, which may be due to spatial heterogeneity or to the existence of spatial spill-overs. ${ }^{10}$ This aspect should be investigated with respect to Ukrainian regions in future studies. Therefore, the baseline model used in this study should be augmented to account for spatial associations for a simple and flexible estimation strategy that would allow for the accounting of spatial spill-overs or spatial dependence using ,for example, the SLX model recently advocated by Vega and Elhorst (2015).

\footnotetext{
${ }^{10}$ See, for example, Dettori et al. (2012) and Marrocu and Paci (2012).
}

Appendix

Table A1. Distribution of firms across sectors (KVED 2-digit)

\begin{tabular}{|c|c|c|}
\hline $\begin{array}{c}\text { KVED 2-digit } \\
\text { number }\end{array}$ & Description of the sector & $\begin{array}{c}\text { number of } \\
\text { firms }\end{array}$ \\
\hline 15 & Food and Beverage & 2,192 \\
\hline 17 & Textile industry & 206 \\
\hline 20 & Publishing, printing industry, reproduction of printed materials & 615 \\
\hline 22 & Manufacture of coke, refined petroleum products and nuclear fuel & 1,252 \\
\hline 23 & Rubber and plastic industries & 61 \\
\hline 24 & Manufacture of other non-metallic mineral products & 596 \\
\hline 25 & Metallurgy & 667 \\
\hline 26 & Metal recycling & 908 \\
\hline 27 & Manufacture of machinery and equipment & 203 \\
\hline 28 & Production and office computers & 927 \\
\hline 29 & Manufacture of electrical machinery and apparatus & 1,569 \\
\hline 30 & Production of equipment for radio, television and communication & 129 \\
\hline 31 & Manufacture of medical apparatus and instruments, precise measuring & 613 \\
\hline 32 & devices, optical devices and watches & 191 \\
\hline 33 & Vehicle production & 442 \\
\hline 34 & Manufacture of other transport equipment & 184 \\
\hline 35 & Manufacture of furniture, other production & 230 \\
\hline 36 & Total & 11,557 \\
\hline & r & \\
\hline
\end{tabular}

Source: Derzhkomstat 2015, Derzhavniy Komitet Statystyky Ukrainy. Available from \&lt;www.ukrstat.gov.ua\&gt;: 
MISCELLANEA GEOGRAPHICA - REGIONAL STUDIES ON DEVELOPMENT

Vol. 21 • No. 1 • 2017 • pp. 44-50 • ISSN: 2084-6118 • DOI: 10.1515/mgrsd-2017-0004

Table A2. Distribution of firms by size

\begin{tabular}{|c|c|c|c|c|c|}
\hline & & $\begin{array}{c}\text { Total number } \\
\text { of firms in the } \\
\text { economy }\end{array}$ & $\begin{array}{c}\text { Share of total } \\
\text { firms }\end{array}$ & $\begin{array}{c}\text { Total number } \\
\text { of firms in the } \\
\text { sample }\end{array}$ & $\begin{array}{c}\text { Share of firms in } \\
\text { the sample total }\end{array}$ \\
\hline Large-sized & $\begin{array}{c}\text { Average number of employees is } \\
\text { more than 250, and annual income is } \\
\text { above EUR 50 mln }\end{array}$ & 659 & $\approx 91$ & $9 \%$ \\
\hline Medium-sized & All other firms & 19,210 & $1 \%$ & 2,437 & $21 \%$ \\
\hline Small-sized & $\begin{array}{c}\text { Average number of employees is less } \\
\text { than 50, and annual income is below } \\
\text { EUR } 10 \text { mln }\end{array}$ & 170,2201 & $99 \%$ & 8,129 & $70 \%$ \\
\hline Total & & 1,722070 & & 11,557 & \\
\hline
\end{tabular}

Source: Derzhkomstat 2015, Derzhavniy Komitet Statystyky Ukrainy. Available from \&lt;www.ukrstat.gov.ua\&gt;:

Table A3. Key characteristics for Ukrainian regions

\begin{tabular}{|c|c|c|c|c|}
\hline Region & $\begin{array}{c}\text { Number of firms, } \\
2013\end{array}$ & $\begin{array}{l}\text { Region's share of the total } \\
\text { number of firms in Ukraine }\end{array}$ & $\begin{array}{c}\text { Number of firms, } \\
2013\end{array}$ & $\begin{array}{l}\text { Region's share of the of the } \\
\text { sample of enterprises }\end{array}$ \\
\hline Cherkasy & 45,399 & $3 \%$ & 317 & $3 \%$ \\
\hline Chernihiv & 36,717 & $2 \%$ & 207 & $2 \%$ \\
\hline Chernivtsi & 35,179 & $2 \%$ & 137 & $1 \%$ \\
\hline $\begin{array}{c}\text { Dnipro } \\
\text { (Dnipropetrovsk) } \\
\end{array}$ & 106,973 & $6 \%$ & 895 & $8 \%$ \\
\hline Donetsk & 145,730 & $8 \%$ & 895 & $8 \%$ \\
\hline Ivano-Frankivsk & 41,334 & $2 \%$ & 223 & $2 \%$ \\
\hline Kharkiv & 119,798 & $7 \%$ & 948 & $8 \%$ \\
\hline Kherson & 40,288 & $2 \%$ & 169 & $1 \%$ \\
\hline Khmelnytskyi & 45,858 & $3 \%$ & 260 & $2 \%$ \\
\hline Kirovograd & 33,577 & $2 \%$ & 225 & $2 \%$ \\
\hline Crimea & 97,588 & $6 \%$ & 392 & $3 \%$ \\
\hline Kyiv & 270,475 & $16 \%$ & 2,515 & $22 \%$ \\
\hline Luhansk & 75,320 & $4 \%$ & 416 & $4 \%$ \\
\hline Lutsk & 32,237 & $2 \%$ & 183 & $2 \%$ \\
\hline Lviv & 82,757 & $5 \%$ & 725 & $6 \%$ \\
\hline Mykolaiv & 52,489 & $3 \%$ & 241 & $2 \%$ \\
\hline Odesa & 113,522 & $7 \%$ & 499 & $4 \%$ \\
\hline Poltava & 52,794 & $3 \%$ & 347 & $3 \%$ \\
\hline Rovno & 33,841 & $2 \%$ & 201 & $2 \%$ \\
\hline Sumy & 28,936 & $2 \%$ & 193 & $2 \%$ \\
\hline Ternopil & 31,487 & $2 \%$ & 191 & $2 \%$ \\
\hline Uzhgorod & 39,092 & $2 \%$ & 199 & $2 \%$ \\
\hline Vinnytsia & 53,481 & $3 \%$ & 338 & $3 \%$ \\
\hline Zaporizhia & 69,912 & $4 \%$ & 529 & $5 \%$ \\
\hline Zhytomyr & 37,286 & $2 \%$ & 311 & $3 \%$ \\
\hline Total & $1,722,070$ & $100 \%$ & 11,556 & $100 \%$ \\
\hline
\end{tabular}


Continued Table A3. Key characteristics for Ukrainian regions

\begin{tabular}{|c|c|c|c|c|}
\hline Region & $\begin{array}{c}\text { Number of firms, } \\
\mathbf{2 0 1 3}\end{array}$ & $\begin{array}{c}\text { Region's share of the total } \\
\text { number of firms in Ukraine }\end{array}$ & $\begin{array}{c}\text { Number of firms, } \\
\mathbf{2 0 1 3}\end{array}$ & $\begin{array}{c}\text { Region's share of the of the } \\
\text { sample of enterprises }\end{array}$ \\
\hline Source & $\begin{array}{c}\text { Diyalnost } \\
\text { pidpriemstv 2013. } \\
\text { Ukrstat }\end{array}$ & $\begin{array}{c}\text { Diyalnost pidpriemstv 2013. } \\
\text { Ukrstat }\end{array}$ & Sample & Sample \\
\hline
\end{tabular}

Source: Derzhkomstat 2015, Derzhavniy Komitet Statystyky Ukrainy. Available from \&lt;www.ukrstat.gov.ua\&gt;.

Table A4. Distribution of firms across Ukrainian regions

\begin{tabular}{|c|c|c|c|c|}
\hline Region & $\begin{array}{c}\text { Number of firms, } \\
2013\end{array}$ & $\begin{array}{l}\text { Region's share of the total } \\
\text { number of firms in Ukraine }\end{array}$ & $\begin{array}{l}\text { Number of } \\
\text { firms, } 2013\end{array}$ & $\begin{array}{l}\text { Region's share of the } \\
\text { sample of enterprises }\end{array}$ \\
\hline Cherkasy & 45,399 & $3 \%$ & 317 & $3 \%$ \\
\hline Chernihiv & 36,717 & $2 \%$ & 207 & $2 \%$ \\
\hline Chernivtsi & 35,179 & $2 \%$ & 137 & $1 \%$ \\
\hline Dnipropetrovsk & 106,973 & $6 \%$ & 895 & $8 \%$ \\
\hline Donetsk & 145,730 & $8 \%$ & 895 & $8 \%$ \\
\hline Ivano-Frankivsk & 41,334 & $2 \%$ & 223 & $2 \%$ \\
\hline Kharkiv & 119,798 & $7 \%$ & 948 & $8 \%$ \\
\hline Kherson & 40,288 & $2 \%$ & 169 & $1 \%$ \\
\hline Khmelnytskyi & 45,858 & $3 \%$ & 260 & $2 \%$ \\
\hline Kirovograd & 33,577 & $2 \%$ & 226 & $2 \%$ \\
\hline Crimea & 97,588 & $6 \%$ & 392 & $3 \%$ \\
\hline Kyiv & 270,475 & $16 \%$ & 2,515 & $22 \%$ \\
\hline Luhansk & 75,320 & $4 \%$ & 416 & $4 \%$ \\
\hline Lutsk & 32,237 & $2 \%$ & 183 & $2 \%$ \\
\hline Lviv & 82,757 & $5 \%$ & 725 & $6 \%$ \\
\hline Mykolaiv & 52,489 & $3 \%$ & 241 & $2 \%$ \\
\hline Odesa & 113,522 & $7 \%$ & 499 & $4 \%$ \\
\hline Poltava & 52,794 & $3 \%$ & 347 & $3 \%$ \\
\hline Rovno & 33,841 & $2 \%$ & 201 & $2 \%$ \\
\hline Sumy & 28,936 & $2 \%$ & 193 & $2 \%$ \\
\hline Ternopil & 31,487 & $2 \%$ & 191 & $2 \%$ \\
\hline Uzhgorod & 39,092 & $2 \%$ & 199 & $2 \%$ \\
\hline Vinnytsia & 53,481 & $3 \%$ & 338 & $3 \%$ \\
\hline Zaporizhia & 69,912 & $4 \%$ & 529 & $5 \%$ \\
\hline Zhytomyr & 37,286 & $2 \%$ & 311 & $3 \%$ \\
\hline Total & $1,722,070$ & $100 \%$ & 11,557 & $100 \%$ \\
\hline Source & $\begin{array}{c}\text { Diyalnost } \\
\text { pidpriemstv } 2013 . \\
\text { Ukrstat }\end{array}$ & $\begin{array}{c}\text { Diyalnost pidpriemstv } 2013 . \\
\text { Ukrstat }\end{array}$ & Sample & Sample \\
\hline
\end{tabular}

Source:Derzhkomstat 2015, Derzhavniy Komitet Statystyky Ukrainy. Available from \&lt;www.ukrstat.gov.ua\&gt;. 
MISCELLANEA GEOGRAPHICA - REGIONAL STUDIES ON DEVELOPMENT

Vol. 21 • No. 1 • 2017 • pp. 44-50 • ISSN: 2084-6118 • DOI: 10.1515/mgrsd-2017-0004

Table A5. Correlations between variables

\begin{tabular}{|c|c|c|c|c|c|c|c|c|}
\hline & TFP & personal & KLratio & import & export & private & foreign & HHI \\
\hline TFP & 1 & & & & & & & \\
\hline personal & .1324 & 1 & & & & & & \\
\hline KLratio & .1134 & -.0001 & 1 & & & & & \\
\hline import & .0944 & .1328 & -.0044 & 1 & & & & \\
\hline export & .0211 & .1196 & -.0064 & .4520 & 1 & & & \\
\hline private & .0388 & .0072 & .0059 & .0492 & .0545 & 1 & & \\
\hline foreign & .0004 & -.0007 & .0034 & .0544 & .0395 & .0348 & 1 & \\
\hline HHI & .0283 & .0701 & .0034 & .0592 & .0547 & .0525 & -.0074 & 1 \\
\hline
\end{tabular}

Source: own calculations of the authors

\section{References}

Brown, J, David, J, Earle, S \& Telegdy, Á 2006, 'The productivity effects of privatization: longitudinal estimates from Hungary, Romania, Russia, and Ukraine', Journal of Political Economy, vol. 114, no. 1, pp. 61-99. Available from: <http:// dx.doi.org/10.1086/499547>. [February 2006]

Cieslik, A, Michalek, J \& Nasadiuk, I 2015, 'Determinants of export performance of Ukrainian firms', Equilibrium. Quarterly Journal of Economics and Economic Policy, Institute of Economic Research, vol. 10, no. 3, pp. 91-103. Available from: <http://dx.doi.org/10.12775/EQUIL.2015.026 >.

Derzhkomstat 2015, Derzhavniy Komitet Statystyky Ukrainy. Available from <www.ukrstat.gov.ua>.

Dettori, B, Marrocu, E \& Paci, R 2012, 'Total factor productivity, intangible assets and spatial dependence in the European regions', Regional Studies, vol. 46, pp. 1401-1416.

Earle, J \& Gehlbach, S 2014, 'Productivity consequences of political turnover: Firm-level evidence from Ukraine's Orange Revolution', IZA Discussion Paper no. 8510. Available from $<$ ftp.iza.org/dp8510.pdf>. [September 2014]

Kim, P H, Jacho-Chavez, D T, Kryvtsov, O, Shepotylo, O \& Vakhitov, V 2015, 'The evolution of firm-level distributions for Ukrainian manufacturing firms', Journal of Comparative Economics, vol. 44, issue 1, pp. 148-162. Available from: $\quad<$ http://www.sciencedirect.com/science/article/pii/ S0147596715000864>. [February 2016]. DOI:10.1016/j. jce.2015.10.004.

KVED-2005 classification 2005. Available from: <http://www. dkrp.gov.ua/info/842>.

KVED-2010 classification 2010. Available from: <http://minfin. com.ua/taxes/-/normdoc/kved2010.html>.
Levinsohn, J \& Petrin, A 2003, 'Estimating production functions using inputs to control for unobservables', Review of Economic Studies, vol. 70, no. 2, pp. 317-341. Available from: < https://www.theigc.org/wp-content/uploads/2016/06/ READINGS-Levinsohn-Petrin.pdf>. [6 August 2013]. DOI: 10.1111/1467-937X.00246.

Marrocu, E \& Paci, R 2012, 'Education or just creativity: what matters most for economic performance?' Economic Geography, vol. 88, pp. 369-401.

Melitz, M 2003, 'The impact of trade on intra-industry reallocations and aggregate industry productivity', Econometrica, vol. 71, no. 6 , pp. $1695-1725$.

Pivovarsky, A 2003, 'Ownership concentration and performance in Ukraine's enterprises', IMF Staff Papers, vol. 50, no. 1. Available from: <https://www.imf.org/external/pubs/.../Pivov.pdf>.

Shepotylo, O \& Vakhitov, V 2015, 'Services liberalization and productivity of manufacturing firms', Economics of Transition, vol. 23, no. 1, pp. 1-44.

Syverson, C 2011, 'What determines productivity?' Journal of Economic Literature, vol. 49, no. 2, pp. 326-365.

Vega, SH \& Elhorst, JP 2015, 'The SLX model', Journal of Regional Science, vol. 55, pp. 339-363.

Wagner, J 2007, 'Exports and productivity: A survey of the evidence from firm-level data', World Economy, vol. 30, no. 1, pp. 60-82.

Wagner, J 2012, 'International trade and firm performance: A survey of empirical studies since 2006', Review of World Economy, vol. 148, pp. 235-267. 